\title{
Salinity-induced changes in ammonia excretion rate of the shrimp Crangon crangon over a winter tidal cycle
}

\author{
Michèle Regnault* \\ CNRS, L.P. 4601 et Univ. P. et M. Curie (Paris 6), Station Biologique de Roscoff, France
}

\begin{abstract}
Effects of tidal fluctuations in salinity on ammonia excretion in the shrimp Crangon crangon L. were studied. The salinity cycles produced under laboratory conditions simulated winter in situ conditions $\left(20 \%, 11^{\circ} \mathrm{C}\right)$. Rate of ammonia excretion $\left(\mu \mathrm{g} \mathrm{N} \mathrm{g}^{-1}\right.$ wet $\left.\mathrm{W} \mathrm{h}^{-1}\right)$ doubles during ebb tide as salinity drops from $34 \%$ to $14 \%$, and is reduced to $1 / 3$ during flood tide as the salinity returns to $34 \%$. The excretory response of $C$. crangon is influenced by at least 3 factors: direction of salinity change, salinity range over which the change occurred, and the velocity of this change. The effects of salinity fluctuations on the ammonia excretion rate of $C$. crangon are discussed in relation to the osmoregulatory mechanisms involved in the shrimp's adaptation to changing salinity. The excretory response of $C$. crangon to a winter tidal cycle is compared to that previously observed under summer conditions. The winter response is characterized by a much larger amplitude and a delay in adaptation. This last point is discussed in relation to the size of shrimp and the experimental temperature, both fitted to winter conditions. Total ammonia production over a $12 \mathrm{~h}$ tidal cycle was $167.53 \pm 3.47 \mu \mathrm{g} \mathrm{N}$ $\mathrm{g}^{-1}$ wet wt in shrimp undergoing tidal cycles, and $95.40 \pm 9.83 \mu \mathrm{g} \mathrm{N}$ in shrimp maintained at a constant salinity (34\%). Consequently, shrimp in estuarine conditions face a noticeable nitrogen loss compared to shrimp staying offshore. As opposed to summer conditions where the loss was negligible, some behavioural changes (migration, burrowing) are necessary for shrimp in order to survive winter estuarine conditions without damage.
\end{abstract}

\section{INTRODUCTION}

According to Florkin (1962), adaptation of euryhaline crustaceans to environmental salinity changes results from 2 types of mechanisms: anisosmotic regulation which mainly involves ionic exchanges between blood and external medium, and intracellular isosmotic regulation, or cell osmotic pressure adaptation, in which amino-acids play a prevailing part (Schoffeniels and Gilles, 1970). In conjunction with this, significant changes in ammonia excretion rate were observed in crustaceans (Needham, 1957; Jeuniaux and Florkin, 1961; Haberfield et al., 1975; Mangum et al., 1976; Farmer and Reeve, 1978; Armstrong et al., 1981; Pressley et al., 1981; Spaargaren et al., 1982). However, the salinity effect on nitrogen excretion was

\footnotetext{
- Present address: Centre d'Océanologie et de Biologie marine, Station Biologique, F-29211 Roscoff, France
}

dependent on the species and its osmoregulatory abilities.

The shrimp Crangon crangon L. exhibits strong osmoregulatory abilities, being capable of hyperosmotic regulation at low salinities as well as hypoosmotic regulation at high salinities. In the Penze estuary ( $N$ Brittany, France) where C. crangon can be collected throughout the year, the salinity fluctuates rhythmically with the tide and over wide ranges on account of a maximum $9 \mathrm{~m}$ tidal amplitude and a 0.8 to $3.6 \mathrm{~m}^{3} \mathrm{~s}^{-1}$ river flow. In spring-tide periods, shrimp are exposed to tidal salinity fluctuations ranging from $35 \%$ to $25 \%$ in summer and from $34 \%$ to $14 \%$ in winter. In order to determine the importance of the $C$. crangon population in this estuarine ecosystem, especially its relative importance in the nitrogen remineralization processes, its ammonia production over a tidal cycle has been studied.

A previous study on the effect of a tidal salinity cycle on Crangon crangon's ammonia excretion in summer 
conditions $\left(35-25-35 \%\right.$; $\left.\mathrm{t}=18^{\circ} \mathrm{C}\right)$ showed an inverse relation between salinity and excretion rate (Regnault, 1983a). Excretion rate increased over the ebb phase and decreased over the flood phase of the cycle; however, changes in rate over the whole cycle were asymmetric. The present study reports the salinity-induced changes in ammonia excretion rate of $C$. crangon over a tidal cycle under winter conditions (34-14-34\%; $\mathrm{t}=11^{\circ} \mathrm{C}$ ). The winter salinity cycle was simulated under laboratory conditions as was the summer cycle. The tidal cycles differed from each other in 3 parameters: salinity variation, temperature and shrimp-size (or age). As the last 2 parameters are known to affect the shrimp's osmoregulatory abilities (Weber and Spaargaren, 1970; Dall, 1981; Moreira et al., 1983) they might also affect the excretory response. The effects of both cycles (summer and winter) and their consequences on the estuarine life of $C$. crangon will be discussed.

\section{MATERIALS AND METHODS}

Shrimp were collected in late February 1983 in the Penze estuary. Fig. 1 shows the monthly salinity variations recorded on the collecting area over a tidal cycle at spring tide. Shrimp were maintained in the lab for 1 or 2 wk prior to experiments. During this acclimatization period they were held in plastic buckets, individually supplied with running sea water $(34 \%)$ from an open system, and were fed daily. There was no sand on the bucket bottom in order to suppress the diel activity rhythm of this species. Shrimp between 36 and $40 \mathrm{~mm}$ total length (mean wet weight: $400 \mathrm{mg}$ ) were used; ovigerous females were discarded. As the ammonia excretion rate of Crangon crangon is markedly affected by moult cycle and nutritional level (Regnault, 1979,

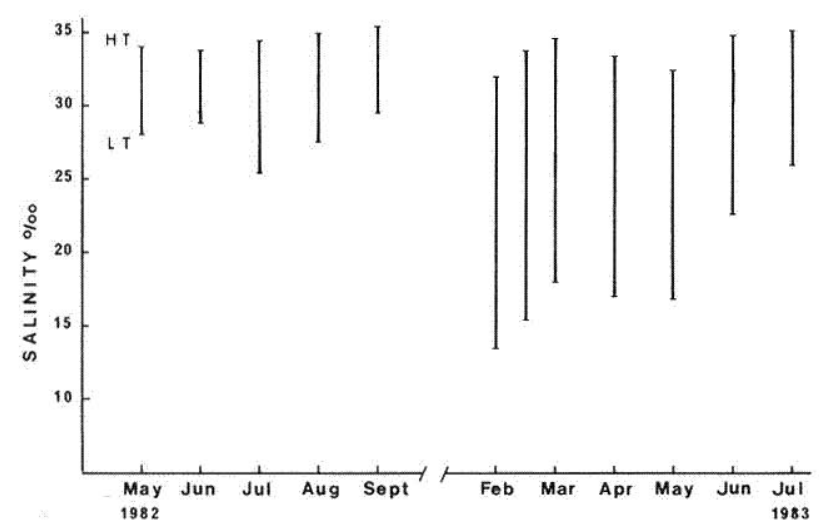

Fig. 1. Amplitude of salinity variation in Penze estuary over a tidal cycle. Salinities were recorded at high tide (HT) and low tide (LT) in the area where shrimp were collected, at spring tide
$1981,1983 b)$, the shrimp were carefully examined the day before the salinity experiments to insure that all experimental individuals were at the $\mathrm{C}$ stage of the moult cycle; these were deprived of food for $12 \mathrm{~h}$. The experimental methods were as previously described (Regnault, 1983a) except for the salinity cycle.

Experimental salinity cycle. Salinity changes were produced by the addition of appropriate amounts of distilled water or concentrated sea water (artificial SW, $70 \%$ prepared from Kalle's recipe, 1945). In contrast to the summer cycle where regular salinity variations $\left(2 \% \mathrm{~h}^{-1}\right)$ were produced, the present salinity variations followed the pattern indicated by Armitage and Morris (1982) in order to be closer to estuarine conditions (Fig. 2). Shrimp had first to cope with a salinity

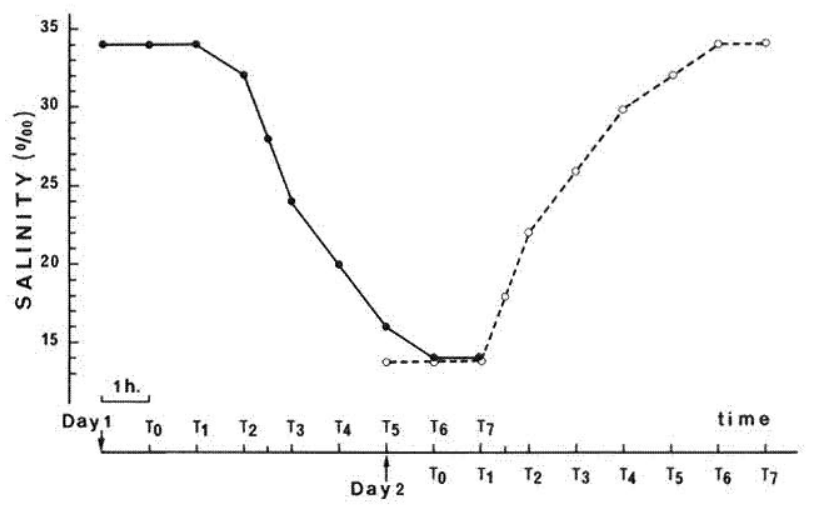

Fig. 2. Laboratory-simulated salinity cycle. Each experiment lasted $8 \mathrm{~h}$; shrimp were first exposed to decreasing salinity (ebb tide $=$ Day 1 ) then to increasing salinity (flood tide $=$ Day 2 )

decrease (Day 1), then to a salinity increase (Day 2). At the end of Day 1 shrimp were fed for $2 \mathrm{~h}$ and transferred to fresh $14 \%$ sea water for the night. This was to avoid adverse effects of a lowered nutritional level and of the increasing ammonia concentration in the experimental jars. Seven simulated tidal cycles were produced, each cycle with a new batch of shrimp.

Excretion measurements. Shrimp were briefly washed in filtered (Millipore: $0.45 \mu \mathrm{m}$ ) sea water, transferred to 61 glass jars filled with filtered sea water, and kept for $8 \mathrm{~h}$ at constant temperature $\left(11^{\circ} \mathrm{C}\right)$. Each experimental set comprised 6 jars: in 5 of them salinity changes were produced (4 experimental jars with 10 shrimp each and a blank without shrimp); in the sixth jar, control shrimp were maintained at constant salinity $(34 \%$ ) and the sea water was renewed following the procedure used for the 5 other jars. During the $8 \mathrm{~h}$ period the ammonia $\left(\mathrm{NH}_{4}-\mathrm{N}\right)$ excreted by the shrimp was measured before every salinity change, using a Technicon autoanalyser as outlined by Le Corre and Treguer (1976). The probe of the Technicon 
sampler was inserted directly into each jar. The first $\mathrm{NH}_{4}-\mathrm{N}$ measurement $\left(\mathrm{T}_{0}\right)$ took place $1 \mathrm{~h}$ after setting the shrimp in the jars; this $\mathrm{T}_{0}$ value indicated the effect of the handling stress which appeared to be substantially reduced by $T_{1}$. Thus, the specific effect of the salinity will refer to the $T_{1}-T_{7}$ period. The hourly excretion rate (HR) was calculated as follows:

$\mathrm{HR}\left(\mu \mathrm{g}\right.$-at $\mathrm{NH}_{4}-\mathrm{N} \mathrm{g}^{-1}$ wet $\left.\mathrm{W} \mathrm{h}^{-1}\right)=\frac{\left(\mathrm{E}_{2}-\mathrm{b}_{2}\right) \mathrm{V}_{2}-\left(\mathrm{E}_{1}-\mathrm{b}_{1}\right) \mathrm{V}_{1}}{\mathrm{~W}}$

where $\mathrm{E}=\mathrm{NH}_{4}-\mathrm{N}$ concentration $\left(\mu \mathrm{g}\right.$-at $\left.\mathrm{l}^{-1}\right)$ in a jar at $\mathrm{T}_{1}$ or $\mathrm{T}_{2} ; \mathrm{b}=\mathrm{NH}_{4}-\mathrm{N}$ concentration in the blank; $\mathrm{V}=$ volume (l) of enclosed sea water in the jar at $T_{1}$ or $T_{2}$; $\mathrm{W}=$ shrimp wet weight $(\mathrm{g})$ in the jar considered. Hourly excretion rate (HR) was finally expressed as: $\mu \mathrm{g} \mathrm{N} \mathrm{g}^{-1}$ wet $\mathrm{W} \mathrm{h}^{-1}$.

\section{RESULTS}

\section{Effect of salinity changes on ammonia excretion}

Salinity decrease (Day 1)

As the salinity gradually decreased from 34 to $14 \%$ the hourly excretion rate increased (Fig. 3). The HR value increased from $11.05 \pm 0.90$ to $22.02 \pm 1.29 \mu \mathrm{g}$ $\mathrm{N} \mathrm{g}^{-1}$ wet wt in the $6 \mathrm{~h}$ period corresponding to the

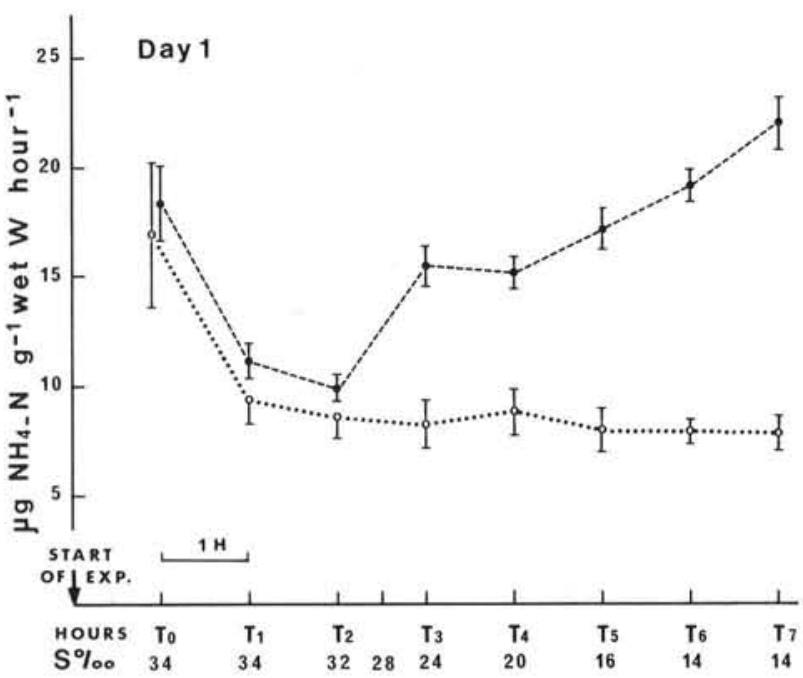

Fig. 3. Crangon crangon. Excretion rate in response to gradual decrease from 34 to $14 \%$ (Day 1 ). $\mathrm{T}_{1}-\mathrm{T}_{6}$ period corresponded to ebb tide phase; $\mathrm{T}_{0}$ : effect of handling stress. Mean values \pm SEM. Filled circles: shrimp undergoing salinity changes $(\mathrm{n}=22$ groups of 10 shrimp); open circles: control shrimp at constant salinity $(n=7$ groups of 10 shrimp)

ebb phase of the tidal cycle. This increase was quite regular from $\mathrm{T}_{4}$ to $\mathrm{T}_{7}$ as the salinity decreased only by $6 \%(20 \rightarrow 14 \%)$. It is worth noting that the HR increase at that time was more marked than the increase observed as the salinity decreased by $8 \%$ in $1 \mathrm{~h}$ $\left(\mathrm{T}_{2}-\mathrm{T}_{3}\right)$. Furthermore, HR was apparently not affected by salinity in the 24 to $20 \%$ range. On the other hand, the high value of the excretion rate at $T_{0}$ obviously showed the effect of handling stress as neither the salinity nor the temperature were changing.

\section{Salinity increase (Day 2)}

As the salinity gradually increased from 14 to $34 \%$ the hourly excretion rate decreased (Fig. 4). The HR value decreased from $19.93 \pm 0.88 \mu \mathrm{g} \mathrm{N} \mathrm{g}^{-1}$ wet wt to $6.22 \pm 0.61$ in the $6 \mathrm{~h}$ period corresponding to the

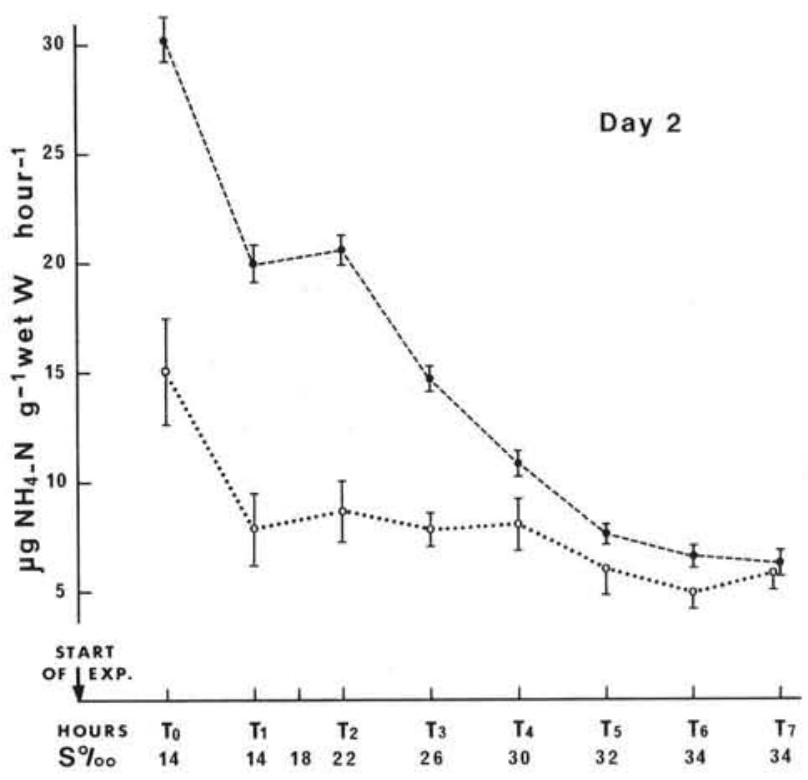

Fig. 4. Crangon crangon. Excretion rate in response to gradual increase from 14 to $34 \%$ (Day 2 ). $T_{1}-\mathrm{T}_{6}$ period corresponded to flood tide phase. For further details consult legend of Fig. 3

flooding phase of the tidal cycle. The HR variation was noticeably more marked than in the reverse situation. However, the low values recorded in the last $2 \mathrm{~h}$ of the experiment for all shrimp (tidal shrimp as well as control shrimp) might indicate the effect of an uncontrolled parameter; thus, the HR values recorded at that time must be considered with caution.

In the first hour of the flood tide phase, as salinity increased from 14 to $22 \%$, the HR was not affected. From $T_{2}$ up to $T_{6}$ the excretion rate regularly decreased even in the 22 to $26 \%$ salinity range where no HR variation was observed as the salinity decreased. Handling stress exerted even more pronounced effects on shrimp at $14 \% \mathrm{~S}$ with a high HR than on shrimp at $34 \%$ S. 
Tidal salinity cycle (Day $1+$ Day 2 )

The change in the hourly excretion rate of Crangon crangon over a composite $12 \mathrm{~h}$ tidal cycle is shown in Fig. 5. For every 2 d experiment, the HR value recorded at $14 \%$ salinity was lower early in Day 2 $(19.93 \mu \mathrm{g} \mathrm{N})$ than late on Day 1 (22.02). The HR following $6 \mathrm{~h}$ (flood phase of the cycle including slack high tide), the difference between the excreted ammonia in $\mathrm{T}$ and $\mathrm{C}$ was not reduced although excretion rate in $\mathrm{T}$ was decreasing. Most of the difference after $9 \mathrm{~h}$ is due to the much higher rate of excretion by shrimp in the ebb phase of the tidal cycle. As the values recorded at the end of Day 2 seemed more or

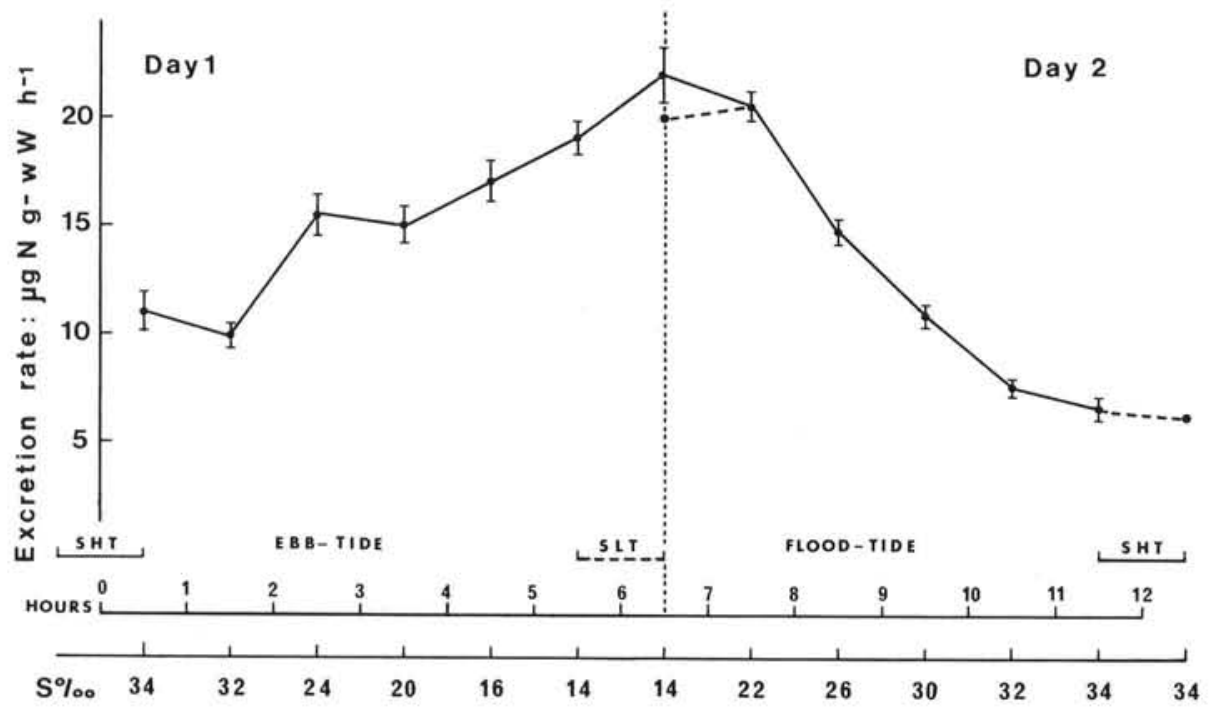

Fig. 5. Crangon crangon. Changes of hourly excretion rate over a composite $12 \mathrm{~h}$ tidal cycle (Day $1+$ Day 2). Mean values \pm SEM $(n=22$ groups of 10 shrimp). SHT: slack high tide; SLT: slack low tide (overnight pause). Values for $T_{1}$ and $T_{7}$ on Day 2 discarded

decrease during the intervening night was an adaptation to low salinity; as it could not occur in situ during the slack low tide, the HR value recorded on Day 2 at $T_{1}$ was not included in the calculation of total production.

The change in the hourly excretion rate over a tidal cycle corresponding to winter conditions exhibited an asymmetric pattern. In the first part, between slack high tide and slack low tide, the hourly excretion rate was doubled; in the second part (back to the consecutive slack high tide) it was reduced to one third. Thus, the excretion rate was lower at the end than at the beginning of a simulated tidal cycle. As far as the excretion rate was concerned, the effect of dilution appeared less important to $C$. crangon than the effect of an equivalent salinity increase.

\section{Ammonia production over a tidal cycle}

The ammonia production of shrimp undergoing salinity changes (T) during a $12 \mathrm{~h}$ tidal cycle was compared to the ammonia production of shrimp maintained all the time at constant salinity (C) (Fig. 6). During the first $6 \mathrm{~h}$ (ebb phase of the cycle including slack low tide), ammonia production was 98.68 and $49.36 \mu \mathrm{g} \mathrm{N} \mathrm{g}^{-1}$ wet $\mathrm{W}$ in $\mathrm{T}$ and $\mathrm{C}$, respectively. In the less reliable (cf. 121) the HR values of the 2 slack high tides ( $T_{1}$ on Day 1 and $T_{7}$ on Day 2 ) were taken into account; so the mean excretion rate at slack high tide was $8.63 \mu \mathrm{g} \mathrm{N} \mathrm{g}^{-1}$ wet $\mathrm{wt} \mathrm{h}^{-1}$.

Ammonia production of shrimp maintained at constant salinity for $12 \mathrm{~h}$ was $95.40 \pm 9.83 \mu \mathrm{g} \mathrm{N} \mathrm{g}-1$ wet wt. Meanwhile, ammonia production of shrimp undergoing tidal salinity changes was $167.53 \pm$ $3.47 \mu \mathrm{g} \mathrm{N}$. The present salinity cycle induces an ammonia production 1.75 times higher than the production at constant salinity. In other words, shrimp lose $70 \mu \mathrm{g} \mathrm{N} \mathrm{g}^{-1}$ wet wt ( $=28 \mu \mathrm{g} \mathrm{N}$ shrimp ${ }^{-1}$ ) compared to shrimp staying at $34 \%$; this represents a $0.30 \%$ loss of their body nitrogen. If such increased loss is maintained through successive tidal cycles, that would cause considerable damage to shrimp under winter estuarine conditions compared to shrimp staying offshore.

To summarize the results, the difference in the excretion rates of tidal (T) and control (C) shrimp versus salinity was plotted (Fig. 7) according to ebb phase (C-A course) and flood phase (B-C course) of the cycle. It appeared that salinity, in some ranges, had no effect on ammonia excretion rate. Furthermore, the plateau observed in the evolution of the $(\mathrm{T}-\mathrm{C})$ value shifted from ( 25 to $18 \%$ ) to ( 22 to $14 \%$ ) depending upon whether the salinity was decreasing or increasing. 


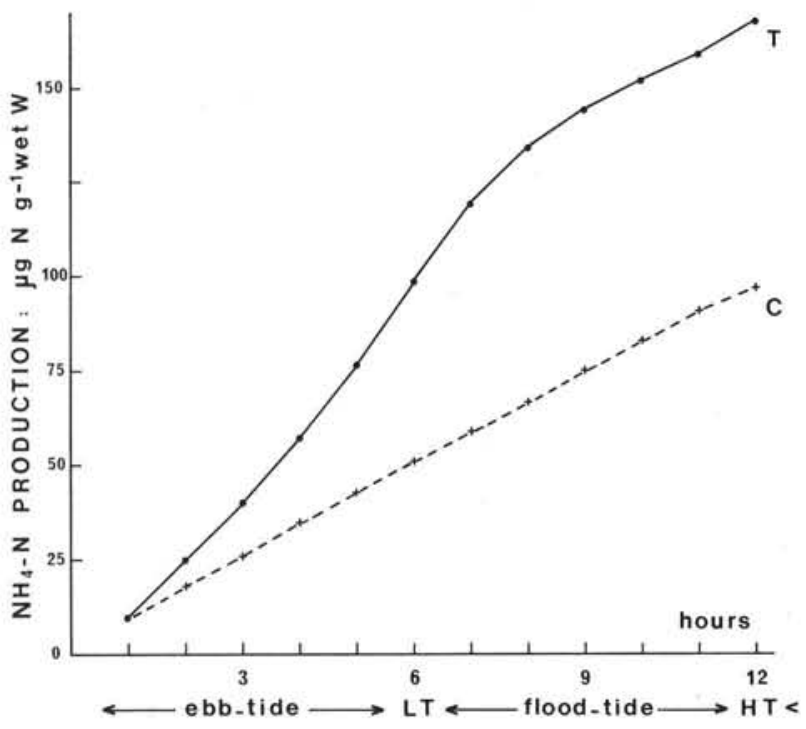

Fig. 6. Crangon crangon. Ammonia production (cumulative values) over a tidal cycle under winter conditions. T: shrimp undergoing tidal salinity changes; $\mathrm{C}$ : control shrimp at constant salinity (34\%)

\section{DISCUSSION}

In euryhaline crustaceans exposed to a salinity gradient over 4 or 5 d Needham (1957) and Jeuniaux and Florkin (1961) observed an increase in nitrogen excretion, mainly ammonia, as salinity decreased, and vice versa. When Crangon crangon was exposed to salinity variations over $6 \mathrm{~h}$ according to the present estuarine conditions a similar response was observed; its ammonia excretion rate increased from 11.05 to
$22.02 \mu \mathrm{g} \mathrm{N} \mathrm{g}^{-1}$ wet $\mathrm{W} \mathrm{h}^{-1}$ as salinity decreased from 34 to $14 \%$, and decreased from 19.93 to $6.57 \mu \mathrm{g} \mathrm{N}$ as salinity increased from 14 to $34 \%$. Excretion in $C$. crangon responded rather less to decrease than to increase in salinity. This was consistent with the findings for the summer cycle (Regnault, 1983a) and Needham's (1957) and Hagerman's (1971) remarks already discussed by Regnault (1983a). Furthermore, consistent responses to salinity changes of similar amplitude and direction were rarely observed and, in some ranges of values, the salinity change had no effect on ammonia excretion (Fig. 3, 4 and 7). On the other hand, some delay appeared in the excretory response of $C$. crangon to salinity change. This timelag between salinity change and excretory response did not occur during the summer cycle for a salinity change only half as pronounced. Thus, the excretory response of $C$. crangon to a salinity change of a given amplitude appeared to be modulated by at least 3 factors: direction of change, salinity range in which the change occurred, and velocity of change.

In Crangon crangon, the ammonia excretion rate over a whole tidal cycle displayed an asymmetric pattern. A similar asymmetry was found in the summer tidal cycle though less marked. Regnault (1983a) assumed that it might be easier for C. crangon to approach its isosmotic point than to move away from it. This assumption was verified in the present study during the flood phase (HR multiplied by 0.78 from 14 to $24 \%$ and HR $\times 0.40$ from 24 to $34 \%$ ) but not during the ebb phase (HR $\times 1.40$ from 34 to $24 \%$ as well as from 24 to $14 \%$ ).

According to Schoffeniels and Gilles (1970) intracellular isosmotic regulation mainly resulted from varia-
Fig. 7. Crangon crangon. Ammonia excretion versus salinity change. The difference in excretion rates of shrimp undergoing tidal cycle (T) and of control shrimp (C) is plotted against salinity. Ebb-tide: from $\mathrm{C}$ to $\mathrm{A}$ (filled circles and black arrows); flood-tide: from B to C (open circles and arrows); shown is shift of plateau in ammonia excretion; for comparison, the regulation plateau in shrimp acclimated to either 7 or $40 \%$ is presented ( $\star$ from McLusky et al., 1982). Effect of a $2 \mathrm{~h}$ adaptation at $14 \%$ ( $\left.\mathrm{A}^{\prime}\right)$ and at $34 \%\left(\mathrm{C}^{\prime}\right)$ shows time lag of the excretory response

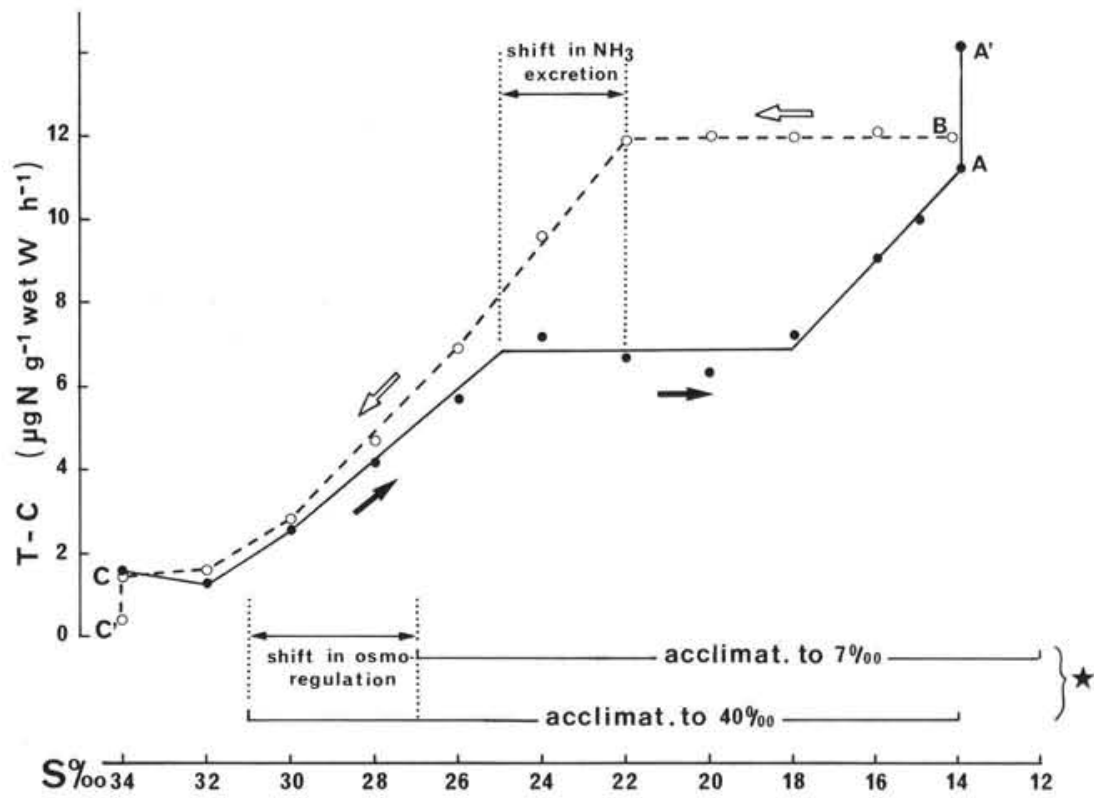


tions of the amino-acid concentrations. These variations could be obtained by either synthesis/breakdown of peptides and proteins (Gilles, 1977; Richard, 1982) or catabolism/synthesis of amino-acids (Campbell, 1973; Schoffeniels, 1976). According to Jeuniaux et al. (1961) and Haberfield et al. (1975), the second possibility would much better justify the changes in ammonia excretion with salinity. However, under simulated tidal conditions close to our own, Armitage and Morris (1982) did not observe any significant changes in amino-acid concentrations over the ebb phase nor the flood phase of the cycle. On the other hand, it was demonstrated that the active sodium uptake following the transfer into a hypotonic medium was related to an increased ammonia output (Mangum et al., 1976; Pressley et al., 1981). By contrast, a reduction of the $\mathrm{Na}^{+} / \mathrm{NH}_{4}{ }^{+}$exchanges (Pequeux and Gilles, 1981) and a possible reversal of these exchanges (Armstrong et al., 1981) were observed following transfer into a hypertonic medium. Such changes with salinity in the $\mathrm{Na}^{+}$and $\mathrm{NH}_{4}{ }^{+}$fluxes as well as in the amino-acid concentrations have to be kept in mind in order to apprehend the variations in the excretion rate of Crangon crangon over a tidal cycle.

The relation between osmoregulatory processes and ammonia excretion rate in Crangon crangon calls for some comments. The reference value of its excretion rate might be the value recorded when the shrimp is close to its isosmotic point (around 22 to $25 \%$ ). Thus, it would be more correct to say that excretion rate increases when shrimp are hyperregulating and, conversely, decreases when they are hyporegulating. On the other hand, it was noticed (Fig. 7) that the excretory response, especially its plateau, could be shifted depending upon whether the salinity was decreasing or increasing. This could result from some adaptative process. At the beginning of the ebb, shrimp were acclimated to a constant high salinity and could likely have undergone a metabolic adjustment as suggested by the low rate recorded at the end of the cycle. The initiation of a similar adaptation could also have occurred during the night at low salinity. The shift of the regulation plateau observed by McLusky et al. (1982) in C. crangon as a result of a $6 \mathrm{wk}$ acclimation to either 7 or $40 \%$ (at $12{ }^{\circ} \mathrm{C}$ ) supports this interpretation.

Many similarities appeared between the excretory responses of Crangon crangon in the summer vs. winter tidal cycle. However, the latter response was characterized by a much greater amplitude and a delay in adaptation to the varying salinity which did not appear in summer conditions. This difficulty of adaptation could be imputed to either shrimp size (or age) or temperature. Staples (1980) and Dall (1981) observed that juveniles of some species were able to adapt extremely well to very low salinities whereas larger shrimp were not. Dall (1981) and Moreira et al. (1983) acknowledged different osmoregulatory abilities in a species according to its developmental phase. On the other hand, a decrease in the osmoregulatory abilities of $C$. crangon at low temperature has been reported (Broekema, 1941; Weber and Spaargaren, 1970). Thus, shrimp size as well as temperature - both characteristic of the winter tidal cycle - could explain the ensuing delay in the winter excretory response.

Because ammonia production of shrimp undergoing a tidal salinity cycle was 1.75 times greater than that of shrimp exposed to constant salinity, it is questionable whether shrimp in estuarine conditions could endure without damage such an increase in their excretion rate at every tidal cycle. The short-term nature of our experiments does not necessarily provide a real estimate of the nitrogen loss by the shrimp as these were not exposed to a continuing cycle of concentrations or dilutions. However, by using the same methodology, it was demonstrated that the nitrogen loss resulting from tidal salinity changes was considerably greater in winter than in summer. Hartsuyker (1966) observed some horizontal tidal migrations in Crangon crangon, the shrimp following ebb and flood. This hypothesis was hardly valid in the present case as shrimp were collected at low tide in the same place where the salinity was recorded. It seemed more likely that shrimp could protect themselves against the low salinities with their burrowing habits as observed in the stenohaline Ovalipes ocellatus (Birchard et al., 1982). As the salinity is noticeably less variable in the sediment than in the overlying water, the shrimp would be able, by burrowing, to avoid damaging nitrogen loss. Al-Adhub and Naylor (1975) observed in $C$. crangon a circatidal emergence rhythm; several factors except salinity were considered by these authors as being responsible for this rhythm. It seemed from this study that tidal salinity changes, especially in winter conditions, could also have some importance.

In summary, the effect of a tidal salinity cycle on the ammonia excretion rate of Crangon crangon presented many similarities in summer and winter: increased ammonia production and nitrogen loss. Yet, the final result would be more drastic for $C$. crangon in winter than in summer, unless shrimp escaped it by behavioural modifications.

Acknowledgements. I thank Dr. John C. Aldrich for generous advice and criticism. His synthetic plot (Fig. 7), emphasizing my results, improves the manuscript a lot and I am particularly grateful to John for this unselfish help.

\section{LITERATURE CITED}

Al-Adhub, A. H. Y., Naylor, E. (1975). Emergence rhythms and tidal migrations in the brown shrimp Crangon crangon (L.). J. mar. biol. Ass. U.K. 55: 801-810 
Armitage, M. E., Morris, R. J. (1982). The effect of changing environmental salinity on the free amino-acid composition of an estuarine population of Neomysis integer. Estuar. coast. Shelf Sci. 14: 301-311

Armstrong, D. A., Strange, K., Crowe, J., Knight, A., Simmons, M. (1981). High salinity acclimation by the prawn Macrobrachium rosenbergii: uptake of exogenous ammonia and changes in endogenous nitrogen compounds. Biol. Bull. mar, biol. Lab., Woods Hole 160: 349-365

Birchard, G. F., Drolet, L., Mantel, L. H. (1982). The effect of reduced salinity on osmoregulation and oxygen consumption in the lady crab Ovalipes ocellatus (Herbst). Comp. Biochem. Physiol. 71A: 321-324

Broekema, M. M. (1941). Seasonal movements and the osmotic behaviour of the shrimp Crangon crangon L. Archs néerl. Zool. 6: 1-100

Campbell, J. W. (1973). Nitrogen excretion. In: Prosser, C. L. (ed.) Comparative animal physiology, 3rd ed. Saunders Company, Philadelphia, p. 279-316

Dall, W. (1981). Osmoregulatory ability and juvenile habitat preference in some penaeid prawns. J. exp. mar. Biol. Ecol. 54: 55-64

Farmer, L., Reeve, M. R. (1978). Role of the free amino-acid pool of the copepod Acartia tonsa in adjustment to salinity change. Mar. Biol. 48: 311-316

Florkin, M. (1962). La régulation isosmotique intracellulaire chez les Invertébrés marins euryhalins. Bull. Acad. r. Belg. Cl. Sci. 48: $687-694$

Gilles, R. (1977). Effects of osmotic stresses on the protein concentration and pattern of Eriocheir sinensis blood. Comp. Biochem. Physiol. 56A: 109-114

Haberfield, E. C., Haas, L. W., Hammen, C. S. (1975). Early ammonia release by a polychaete Nereis virens and a crab Carcinus maenas in diluted sea water. Comp. Biochem. Physiol. 52A: 501-503

Hagerman, L. (1971). Osmoregulation and sodium balance in Crangon vulgaris (Fabricius) (Crustacea, Natantia) in varying salinities. Ophelia 9: 21-30

Hartsuyker, L. (1966). Daily tidal migrations of the shrimp Crangon crangon L. Netherl. J. Sea Res. 3: 52-67

Jeuniaux, C., Florkin, M. (1961). Modification de l'excrétion azotée du crabe chinois au cours de l'adaptation osmotique. Archs int. Physiol. Biochim. 69: 385-386

Jeuniaux, C., Bricteux-Grégoire, S., Florkin, M. (1961). Contribution des acides aminés libres à la régulation osmotique intracellulaire chez deux Crustacés euryhalins, Leander serratus $\mathrm{F}$, et Leander squilla L. Cah. Biol. mar. 2: 373-380

Kalle, K. (1945). In: Riley, J. P., Skirrow, G. (ed.) Chemical oceanography. 2nd ed., 1975, vol 1, p. 559 (appendix). Academic Press, London

Le Corre, P., Treguer, P. (1976). Contribution à l'étude de la matière organique dissoute et des sels nutritifs dans l'eau de mer. Caractéristiques chimiques du Golfe de Gascogne et des upwellings côtiers d'Afrique N.W. Thèse Doct. Etat, Univ. Bretagne, Occidentale
McLusky, D. S., Hagerman, L., Mitchell, P. (1982). Effect of salinity acclimation on osmoregulation in Crangon crangon and Praunus flexuosus. Ophelia 21: 89-100

Mangum, C. P., Silverthorn, S. U., Harris, J. L., Towle, D. W., Krall, A. R. (1976). The relationship between blood $\mathrm{pH}$, ammonia excretion and adaptation to low salinity in the blue crab Callinectes sapidus. J. exp. Zool. 195: 129-136

Moreira, G. S., McNamara, J. C., Shumway, S. E., Moreira, P. S. (1983). Osmoregulation and respiratory metabolism in Brazilian Macrobrachium (Decapoda, Palaemonidae). Comp. Biochem. Physiol. 74A: 57-62

Needham, A. E. (1957). Factors affecting nitrogen excretion in Carcinides maenas (Pennant). Physiologia comp. Oecol. 4 : 209-239

Pequeux, A., Gilles, R. (1981). $\mathrm{Na}^{+}$fluxes across isolated perfused gills of the chinese crab Eriocheir sinensis. J. exp. Biol. 92: 173-186

Pressley, T. A., Graves, J. S., Krall, A. R. (1981). Amiloride sensitive ammonium and sodium transport in the blue crab. Am. J. Physiol. 241 (Regulatory Integrative comp. Physiol.) 10: R370-R378

Regnault, M. (1979). Ammonia excretion of the sand shrimp Crangon crangon L. during the moult cycle. J. comp. Physiol. B 133: 199-204

Regnault, M. (1981). Respiration and ammonia excretion of the shrimp Crangon crangon L. Metabolic responses to prolonged starvation. J. comp. Physiol. B 141: 549-555

Regnault, M. (1983a). Influence des variations de salinité consécutives au cycle de marée sur l'excrétion ammoniacale de Crangon crangon L. Oceanologica Acta 6: 297-302

Regnault, M. (1983b). Influence à long terme du taux protéique du régime sur l'excrétion d'azote et le métabolisme de la crevette Crangon crangon L. Océanis 9: 241-255

Richard, P. (1982). Role biologique et écologique des acides aminés libres chez quelques Crustacés Décapodes marins. Thèse Doct. Etat, Univ. Aix-Marseille

Schoffeniels, E. (1976). Adaptations with respect to salinity. Biochem. Soc. Symposia 41: 179-204

Schoffeniels, E., Gilles, R. (1970). Osmoregulation in aquatic Arthropods. In: Florkin, M., Scheer, B. T. (ed.) Chemical zoology, Vol. 5, Part A. Academic Press, New York, p. 255-286

Spaargaren, D. H., Richard, P., Ceccaldi, H. J. (1982). Excretion of nitrogenous products by Penaeus japonicus Bate in relation to environmental osmotic conditions. Comp. Biochem. Physiol. 72A: 673-678

Staples, D. J. (1980). Ecology of juvenile and adolescent banana prawns, Penaeus merguiensis in a mangrove estuary and adjacent offshore waters of the Gulf of Carpentaria. II. Emigration, population structure and growth of juveniles. Aust. J. mar. Freshwater Res. 31: 653-665

Weber, R. E., Spaargaren, D. H. (1970). On the influence of temperature on the osmoregulation of Crangon crangon and its significance under estuarine conditions. Neth. J. Sea Res. 5: 108-120 